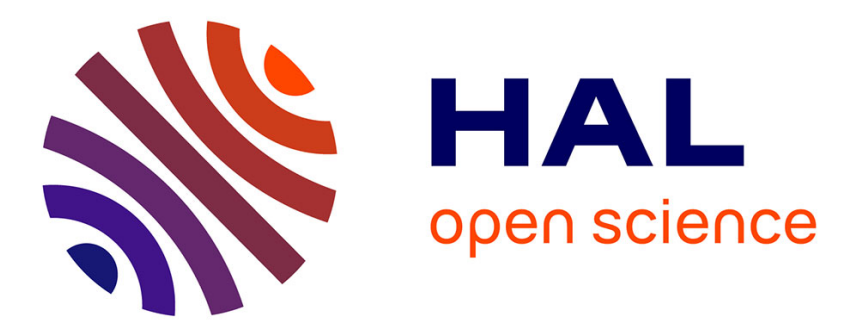

\title{
Relationship Between Gases and Volcanic Activity of Mount Etna in 1986
}

M.F. Le Cloarec, M. Pennisi, B. Ardouin, J. C Le Roulley, G. Lambert

\section{To cite this version:}

M.F. Le Cloarec, M. Pennisi, B. Ardouin, J. C Le Roulley, G. Lambert. Relationship Between Gases and Volcanic Activity of Mount Etna in 1986. Journal of Geophysical Research: Solid Earth, 1988, 93 (B5), pp.4477-4484. 10.1029/JB093iB05p04477 . hal-03551063

\section{HAL Id: hal-03551063 \\ https://hal.science/hal-03551063}

Submitted on 1 Feb 2022

HAL is a multi-disciplinary open access archive for the deposit and dissemination of scientific research documents, whether they are published or not. The documents may come from teaching and research institutions in France or abroad, or from public or private research centers.
L'archive ouverte pluridisciplinaire HAL, est destinée au dépôt et à la diffusion de documents scientifiques de niveau recherche, publiés ou non, émanant des établissements d'enseignement et de recherche français ou étrangers, des laboratoires publics ou privés. 


\title{
Relationship Between Gases and Volcanic Activity of Mount Etna in 1986
}

\author{
M. F. Le Cloarec, M. Pennisi, B. Ardouin, J. C. Le Roulley, and G. Lambert \\ Centre des Fables Radioactivités, Centre National de la Recherche Scientifique/Commissariat à l'Energie Atomique \\ Gif-sur-Y vette, France
}

\begin{abstract}
The long-lived ${ }^{222} \mathrm{Rn}$ decay products $210_{\mathrm{Pb}}{ }^{210_{\mathrm{Bi}}}$ and ${ }^{210} \mathrm{Po}$ have been monitored in the plumes of several vents at Mount Etna (Sicily) from May to October 1986. The results show that the four main craters of this voicano emit gases whose compositions are different from each other. The ${ }^{210} \mathrm{Bi}_{\mathrm{B}} /{ }^{210} \mathrm{~Pb}$ ratios for the plumes have similar mean values, (close to 25), which correspond to a degassing time of 1.5 to 2.7 days, according to the model of Lambert et al. $(1985 / 86)$. In contrast ${ }^{210} \mathrm{Po} / 210 \mathrm{~Pb}$ ratios have very different mean values in each plume: 35 at the Voragine crater, 20 at the Bocca Nuova crater, and 14 at the South East crater. These figures enable us to calculate proportions of deep magma of 50\%, 29\% and $19 \%$ in the degassing cells of these craters respectively. Moreover, the SE crater appears to be a secondary degassing vent, not directly related to the main magma reservoir. The evolution of these ratios has been related to variations in volcanic activity.
\end{abstract}

\section{INTRODUCTION}

Since 1976, several series of measurements on more than 10 volcanoes have shown that large amounts of radioactive lead, bismuth, and polonium are volatilized from the magma surface, and subsequently condensed on volcanic aerosols [Lambert et al., 1976, 1979; Polian and Lambert, 1979; Le Guern, 1982; Le Cloarec et al., 1984]. Moreover, although the $222 \mathrm{Rn}$ decay products $210_{\mathrm{Pb}}, 210_{\mathrm{Bi}}$, and $210_{\mathrm{Po}}$ are presumably in radioactive equilibrium in a deep nondegassed magma, it appears that $210_{\mathrm{Bi}}$ and $210 \mathrm{Po}$ are considerably enriched relative to $210 \mathrm{~Pb}$.

Similar enrichments were observed in volcanic aerosols for most trace metals, and ascribed to volatility differences of their chemical compounds [Buat-Ménard and Arnold, 1978; Cadle et al., 1979 ; Phelan et al., 1982]. A model was proposed by Lambert et al. [1985/86] to account for the activity ratios of radon daughters observed in aerosols from Mount Etna (Sicily). This model was based on the assumption that, in a deep nondegassed magma, ${ }^{226} \mathrm{Ra}$ is in radioequilibrium with its decay products. It has been shown in this model that magmatic gases should be released only when this deep magma is brought to the surface by convection. Moreover, it was observed that freshly emitted lavas do not contain anymore 210 Po [Bennett et al., 1982; Le Cloarec et al., 1984 ; Gill et al., 1985], which is due to the very high volatility of this metal. As $210 \mathrm{Po}$ is present in volcanic aerosols, it is necessary to admit that the shallow degassing cell contains a proportion $(\mu)$ of deep non degassed magma, which can be calculated from the model, using the activity ratio $210 \mathrm{Po} / 210 \mathrm{~Pb}$ of these aerosols. In this model, it is presumed that volatile metal compounds are emitted, from the shallow cell, proportionally to an emanation coefficient $(\varepsilon)$ which is evaluated to be about 1 for polonium, as mentioned above, 0.5 for bismuth, and 0.01 for lead. However, the gas emission is not instantaneous. The time elapsed between the gas phase production in the shallow cell and its emission into the free atmosphere $(\theta)$ is long enough to allow the 5-day half-life $210_{\mathrm{Bi}}$ to decay, so that the measured activity ratios $210_{\mathrm{Bi}} / 210_{\mathrm{Pb}}$ are smaller than the ratio $\varepsilon_{\mathrm{Bi}} / \varepsilon_{\mathrm{Pb}}$. The measurement of these activity ratios in volcanic aerosols gives a means of measuring the values of the outgassing time $\theta$.

This model was successfully applied to data obtained during six short studies performed on Mount Ema from 1976 to 1984, reported by Lambert et al. [1985/86]; however, it was not tested relative to the long-term evolution of this volcano. With this aim, a systematic

Copyright 1988 by the American Geophysical Union.

Paper number 7B7085.

0148-0227/88/007B-7085\$05.00 sampling of aerosols in the Mount Etna plume was organized on a quasi-daily basis, from May to October 1986.

\section{Samping and MeAsurements}

Gases and aerosols are more or less continuously emitted from four craters at the top of Mount Ema (Figure 1): North East crater (NE) at $3300 \mathrm{~m}$ above sea level, Central crater at $3000 \mathrm{~m}$, containing the Bocca Nuova (BN) and the Voragine (V), and South East crater (SE) at about $2900 \mathrm{~m}$. A more detailed description can be found in Chester et al., [1985] and Kieffer and Tanguy [1987].

During the spring of 1986, an important and steady outgassing occurred at the BN and V craters, which carried on during the summer. The magma level in these craters was high, and strong strombolian activity was observed at several spatter cones in the bottom of the craters. At the end of May, a puffing hole was observed inside the SE crater, from which degassing occurred until the end of July. After this period, some ejections of old and fresh lavas were associated with the steady degassing; this typical magmatic activity persisted throughout the summer [Kieffer and Tanguy, 1987].

At the NE crater, a very weak emission of vapors occurred until the end of July, at which time strombolian activity began from a cone growing inside the crater. On Seprember 14, an effusive event started and viscous lavas flowed toward the northwest. After a sudden stop of the activity, on September 24, a phreatomagmatic explosion occurred. At the same time, the activity stopped at the BN and V craters. Then, the NE crater went into a state of weak fumarolic activity, while strombolian activity restared at the $B N$ and $V$ craters.

The technique of sampling and radioactivity measurement was described by Poilian and Lambert [1979]. Several cubic meters of air are filtered through a cellulose filter, at a flow rate of abour $20 \mathrm{~m}^{3}$ per hour. Subsequently, the gross $\alpha$ and $\beta$ radioactivities are measured during a period of several months, and the $210 \mathrm{~Pb}, 210_{\mathrm{Bi}}$ and $210 \mathrm{Po}$ activities at the sampling time can be calculated from the radioactivity decay of material on the filter. The results are listed in Table 1.

According to the volcanic activity and the wind direction, samples were obtained at different places of the Mount Etna summit. These samples are therefore from the emissions of different craters. During the experiment the BN crater was sampled almost every day. Samples from the $\mathrm{V}$ crater were obtained only when it was possible to differenuiate its plume from that of the BN crater. The SE crater approach was sometimes hazardous, which limited its sampling. The NE crater is not easy to reach and was only sampled once. Unfortunately, during the experiment, this crater was the only one whose volcanic activity significantly changed. 


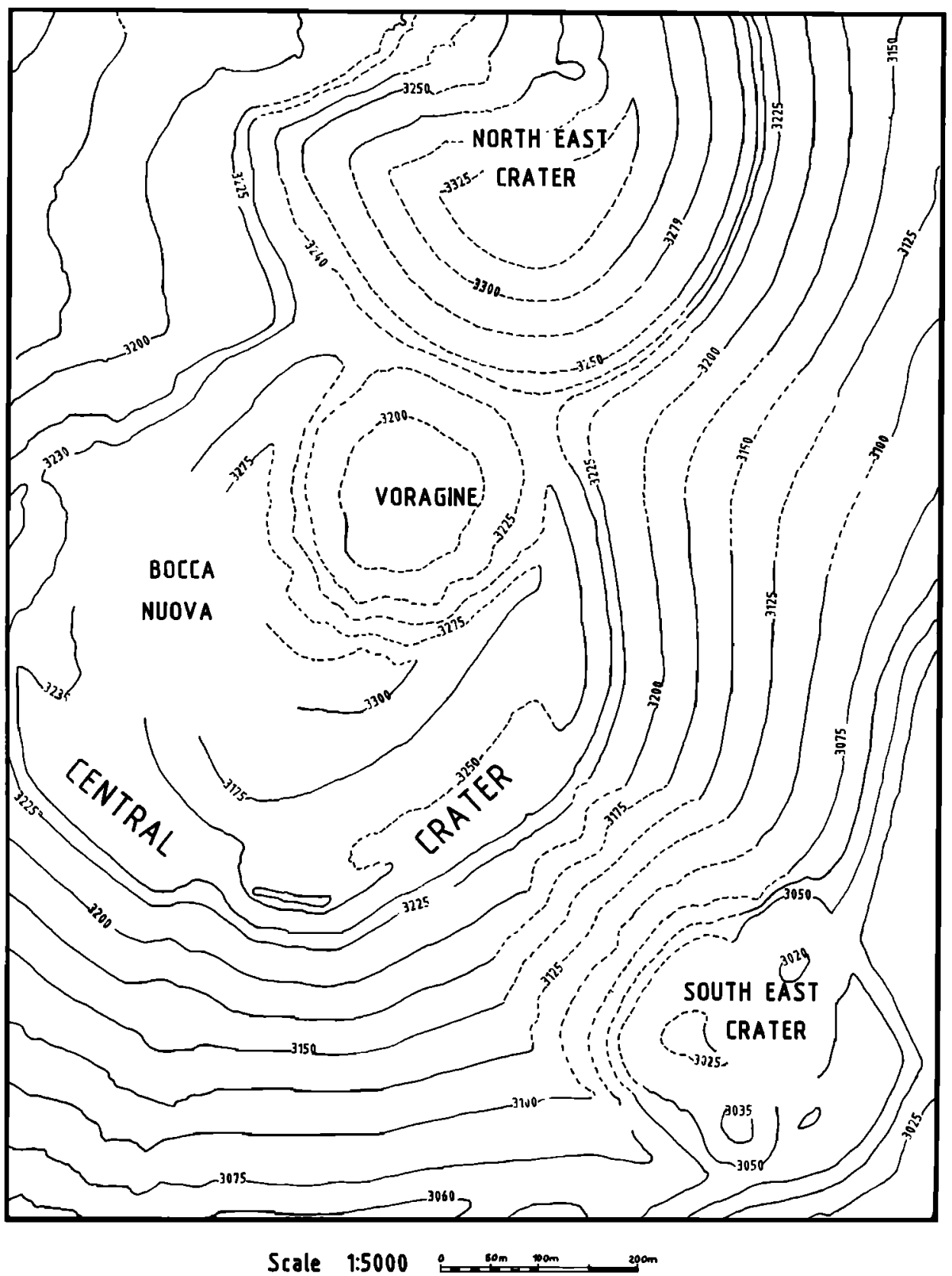

Fig. 1. Map of Mount Etna summit.

\section{Distinction Between Craters}

The results obtained at the BN, V, and SE craters show that all emitted gases are typically magmatic, as indicated by the high values of $210 \mathrm{Bi} / 210 \mathrm{~Pb}$ and $210 \mathrm{Po} / 210_{\mathrm{Pb}}$ ratios [Lambert et al., 1979]. However, they have different compositions from one crater to another.

The $210_{\mathrm{Bi}} / 21 \mathrm{C}_{\mathrm{Pb}}$ ratio has about the same mean value for the three craters $B N, V$, and SE: $22 \pm 4,26 \pm 8$ and $25 \pm 7$, respectively. According to the degassing model, this ratio is related to the outgassing time $\theta$ and therefore to the convective movements in the degassing cell and to its size. The mean values of $\theta$ varied between 1.5 and 2.7 days for the three craters, showing that outgassing conditions during that period were not very different from one crater to another.

On the other hand, the $210 \mathrm{Po} / 210 \mathrm{~Pb}$ ratios had very different mean values in each plume: $35 \pm 10$ at the $\mathrm{V}$ crater, $20 \pm 7$ at the $\mathrm{BN}$ crater, and $14 \pm 8$ at the SE crater. As explained earlier, these figures enable us to calculate the proportion $\mu$ of deep nondegassed magma present in the shallow degassing cell: it is as high as $50 \%$ at the $\mathrm{V}$ crater, but only around $29 \%$ at the $B N$ crater, although both these craters are very close to each other. At the SE crater, $\mu$ is low, about $19 \%$, which shows that this crater is not directly related to the deep magma but is rather a secondary degassing vent

\section{EVOLUTION WITH TIME}

Although mean values of $210 \mathrm{Po} / 210 \mathrm{~Pb}$ and $210_{\mathrm{Bi}} / 210_{\mathrm{Pb}}$ ratios remained largely unchanged during the observation period, they did show some variation, and we tried to find some correlation berween them and volcanic events. Mean values were calculated during shoner periods, for which these ratios appeared as approximately constant. Results are shown 
TABLE 1. Activity Ratios in Aerosols Emitted From the Main Craters of Mount Aetna in 1986, and Dynamical Parameters Deduced

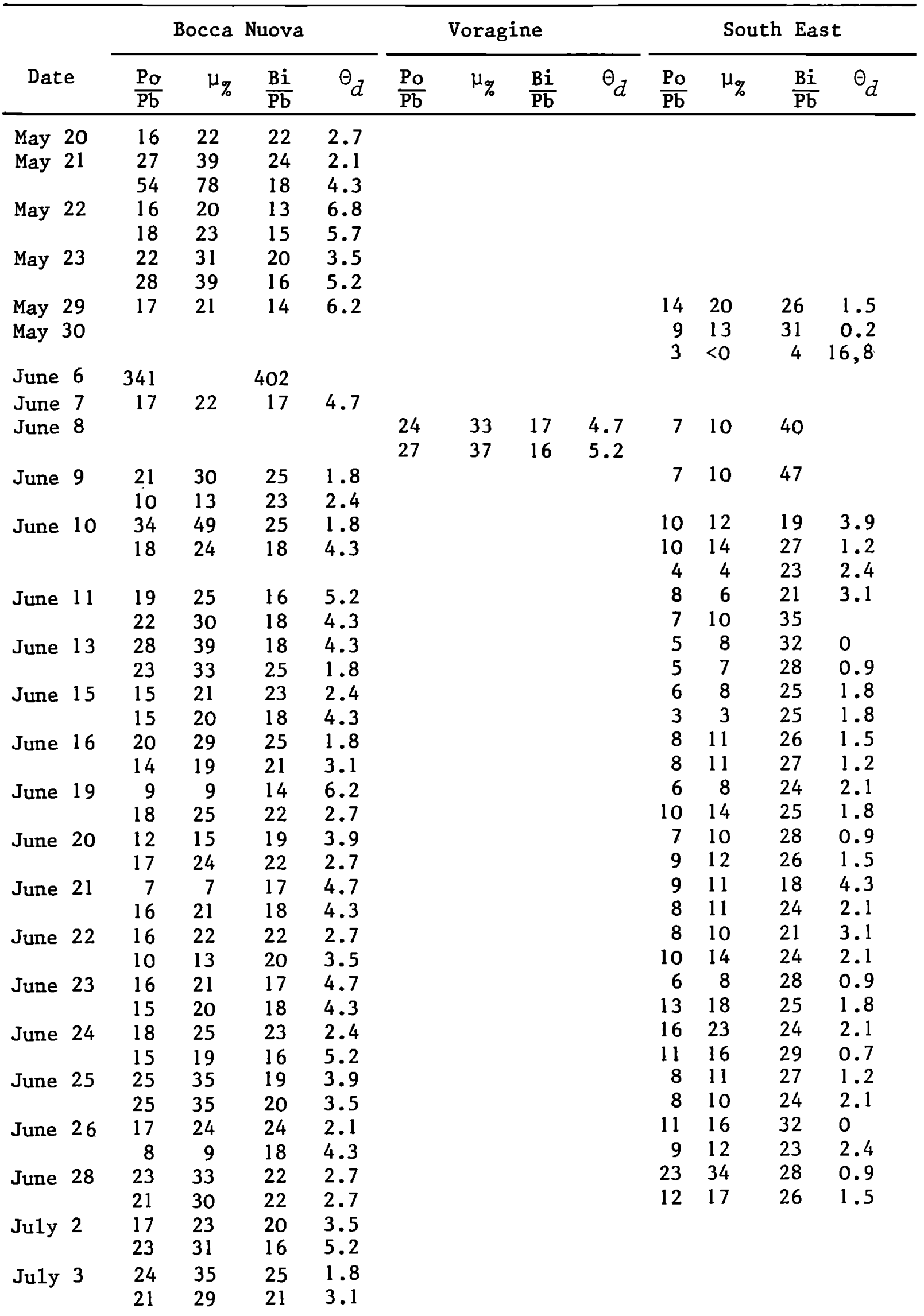


TABLE 1 (continued)

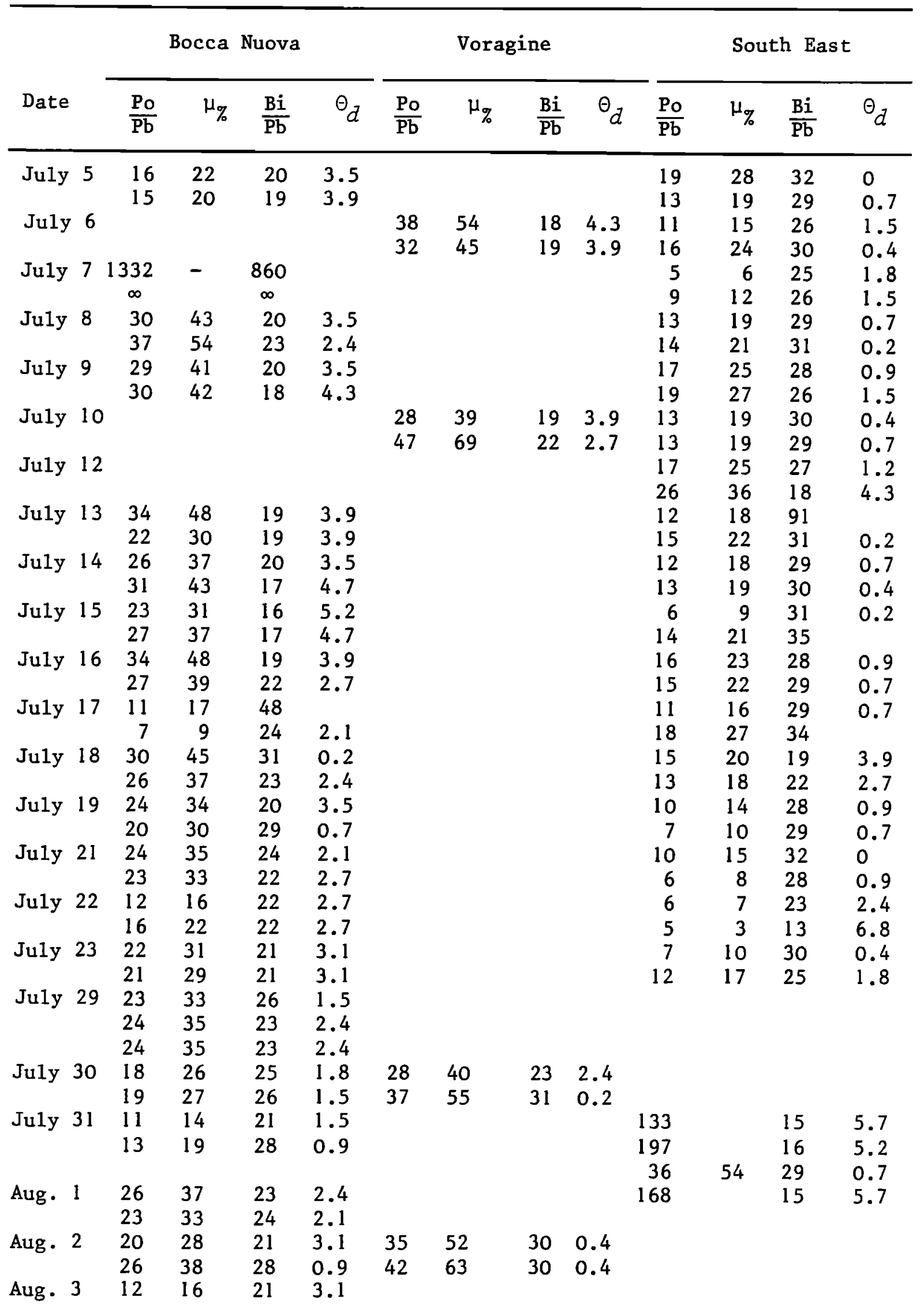


TABLE 1 (continued)

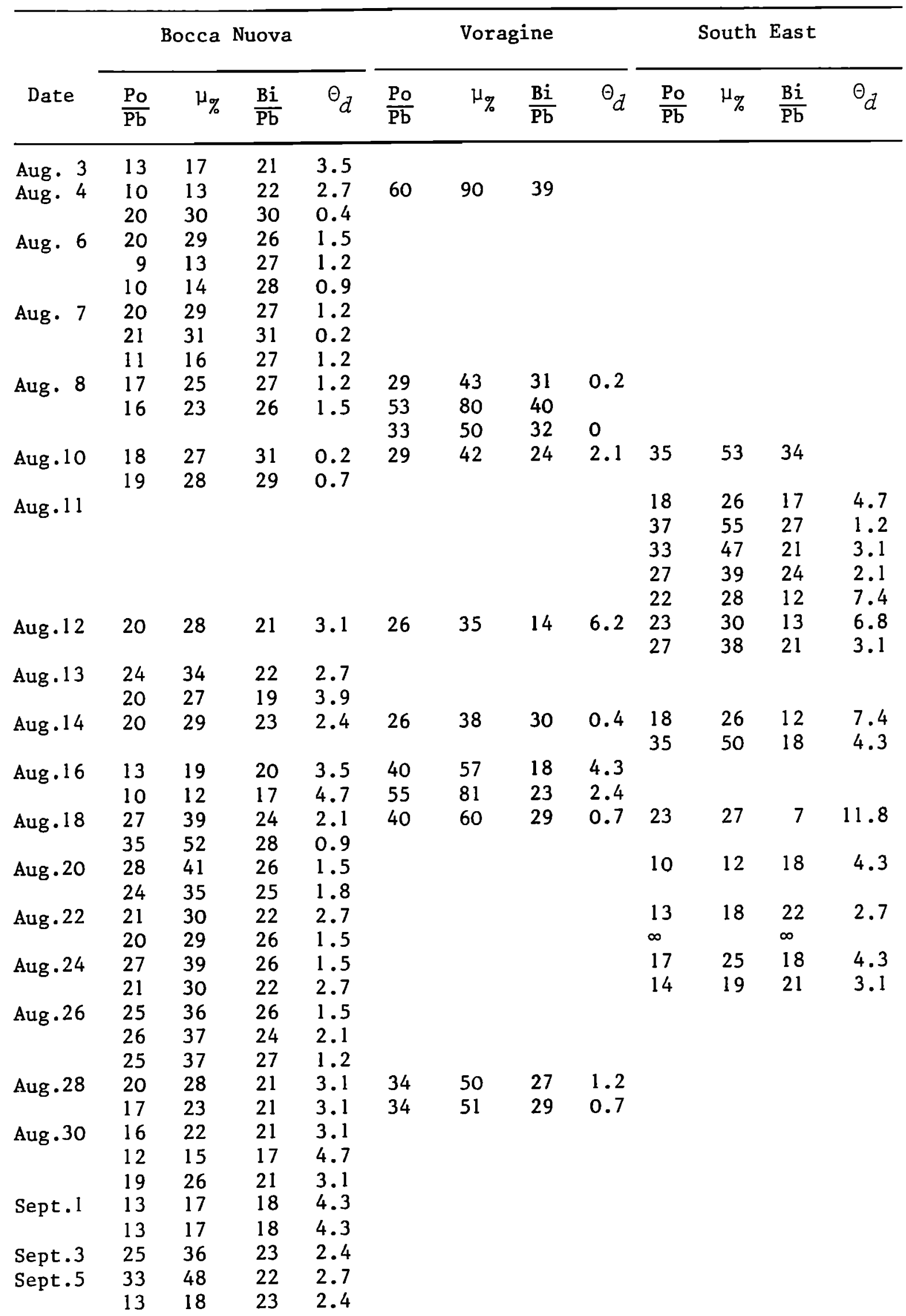


TABLE 1 (continued)

\begin{tabular}{|c|c|c|c|c|c|c|c|c|c|c|c|c|}
\hline \multirow[b]{2}{*}{ Date } & \multicolumn{4}{|c|}{ Bocca Nuova } & \multicolumn{4}{|c|}{ Voragine } & \multicolumn{4}{|c|}{ South East } \\
\hline & $\frac{\mathrm{Po}}{\mathrm{Pb}}$ & $\mu_{\%}$ & $\frac{\mathrm{Bi}}{\mathrm{Pb}}$ & ${ }^{\theta_{d}}$ & $\frac{\mathrm{Po}}{\mathrm{Pb}}$ & $\mu_{\%}$ & $\frac{\mathrm{Bi}}{\mathrm{Pb}}$ & $\theta_{d}$ & $\frac{\mathrm{Po}}{\mathrm{Pb}}$ & $\mu_{\%}$ & $\frac{\mathrm{Bi}}{\mathrm{Pb}}$ & ${ }^{\theta} d$ \\
\hline Sept. 7 & $\begin{array}{l}18 \\
25\end{array}$ & $\begin{array}{l}25 \\
32\end{array}$ & $\begin{array}{l}21 \\
11\end{array}$ & $\begin{array}{l}3.1 \\
8.1\end{array}$ & 41 & 60 & 22 & 2.7 & & & & \\
\hline Sept. 9 & $\infty$ & & $\infty$ & & 38 & 55 & 21 & 3.1 & & & & \\
\hline Sept.11 & $\begin{array}{l}12 \\
41\end{array}$ & $\begin{array}{l}15 \\
62\end{array}$ & $\begin{array}{l}16 \\
82\end{array}$ & 5.2 & & & & & & & & \\
\hline Sept.13 & $\begin{array}{l}20 \\
22\end{array}$ & $\begin{array}{l}29 \\
32\end{array}$ & $\begin{array}{l}24 \\
24\end{array}$ & $\begin{array}{l}2.1 \\
2.1\end{array}$ & & & & & & & & \\
\hline Sept. 15 & $\begin{array}{l}15 \\
18\end{array}$ & $\begin{array}{l}20 \\
25\end{array}$ & $\begin{array}{l}19 \\
22\end{array}$ & $\begin{array}{l}3.9 \\
2.7\end{array}$ & 37 & 54 & 24 & 2.1 & & & & \\
\hline Sept. 17 & $\begin{array}{l}21 \\
16\end{array}$ & $\begin{array}{l}29 \\
22\end{array}$ & $\begin{array}{l}19 \\
21\end{array}$ & $\begin{array}{l}3.9 \\
3.1\end{array}$ & 34 & 51 & 44 & & 13 & 20 & 33 & \\
\hline Sept. 20 & $\begin{array}{l}16 \\
14\end{array}$ & $\begin{array}{l}22 \\
20\end{array}$ & $\begin{array}{l}22 \\
19\end{array}$ & $\begin{array}{l}2.7 \\
3.9\end{array}$ & 43 & 64 & 29 & 0.7 & 19 & 27 & 23 & 2.4 \\
\hline $\begin{array}{l}\text { Sept. } 22 \\
\text { Sept. } 23\end{array}$ & 28 & 40 & 22 & 2.7 & 193 & & 42 & & $\begin{array}{r}12 \\
14 \\
9\end{array}$ & $\begin{array}{l}17 \\
21 \\
12\end{array}$ & $\begin{array}{l}26 \\
29 \\
26\end{array}$ & $\begin{array}{l}1.5 \\
0.7 \\
1.5\end{array}$ \\
\hline Sept. 24 & & & & & & & & & $\begin{array}{l}31 \\
14\end{array}$ & $\begin{array}{l}45 \\
20\end{array}$ & $\begin{array}{l}24 \\
28\end{array}$ & $\begin{array}{l}2.1 \\
0.9\end{array}$ \\
\hline Sept. 29 & 33 & 49 & 30 & 0.4 & 44 & 63 & 18 & 4.3 & $\infty$ & & $\infty$ & \\
\hline Oct. I & 9 & 11 & 19 & 3.9 & 20 & 26 & 14 & 6.2 & $\begin{array}{r}9 \\
31\end{array}$ & $\begin{array}{l}10 \\
40\end{array}$ & $\begin{array}{r}15 \\
8\end{array}$ & $\begin{array}{r}5.7 \\
10.7\end{array}$ \\
\hline Oct. 3 & 25 & 36 & 22 & 2.7 & 42 & 59 & 14 & 6.2 & $\begin{array}{l}14 \\
15\end{array}$ & $\begin{array}{l}19 \\
19\end{array}$ & $\begin{array}{l}21 \\
16\end{array}$ & $\begin{array}{l}3.1 \\
5.2\end{array}$ \\
\hline & 33 & 47 & 21 & 3.1 & & & & & $\begin{array}{l}12 \\
10\end{array}$ & $\begin{array}{l}16 \\
13\end{array}$ & $\begin{array}{l}21 \\
20\end{array}$ & $\begin{array}{l}3.1 \\
3.5\end{array}$ \\
\hline $\begin{array}{l}\text { Oct. } 9 \\
\text { Oct. } 12 \\
\text { Oct. } 15\end{array}$ & $\begin{array}{l}12 \\
18 \\
21\end{array}$ & $\begin{array}{l}16 \\
23 \\
31\end{array}$ & $\begin{array}{l}22 \\
15 \\
28\end{array}$ & $\begin{array}{l}2.7 \\
5.7 \\
0.9\end{array}$ & & & & & $\begin{array}{r}5 \\
18\end{array}$ & $\begin{array}{r}3 \\
26\end{array}$ & $\begin{array}{l}12 \\
28\end{array}$ & $\begin{array}{l}7.4 \\
0.9\end{array}$ \\
\hline $\begin{array}{l}\text { Mean } \\
\text { North Eas } \\
\text { crater } \\
\text { Sept. } 22\end{array}$ & $\begin{array}{l}20 \pm 7 \\
\text { st } \\
35\end{array}$ & 29 & $22 \pm 4$ & 2.7 & $35 \pm 10$ & 51 & $26 \pm 8$ & 1.5 & $14 \pm 8$ & 19 & $25 \pm 7$ & 1.8 \\
\hline
\end{tabular}

in Table 2, for the BN and SE craters, and are reported in Figure 2, together with all data obtained at the $\mathrm{V}$ crater, as they are too few to allow mean values significant calculations.

At the BN crater, the outgassing time $\theta$ decreased regularly from 3.9 days to 1.8 days between May and August, then returned to around 3 days in September. During that time, $\mu$ did not show any special trend, varying between $20 \%$ and $35 \%$, which is consistent with the steady activity of the crater. Moreover, it seems that neither the observed events at the NE crater in August and September, nor the evolution of the SE crater activity during that period, affected the degassing .

The SE crater was usually characterized by low values of $\mu$ (below $20 \%$ ) and short escape times, around 1 or 2 days, except in August, when the NE crater began to be active; at that time, $\theta$ increased to 4.7 days and $\mu$ to around $40 \%$. Similarly, at the $V$ crater, for which $\theta$ values were generally of the order of 4 days and $\mu$ around $50 \%$, two periods of perturbation were observed. The first one also took place in August, when $\theta$ decreased to as low as 1 day, and the second one at the time of the lava effusion at the NE crater, an important degassing of deep magma then occurred, as indicated by high values of $210 \mathrm{Po} / 210_{\mathrm{Pb}}$ and $210 \mathrm{Bi} / 210_{\mathrm{Pb}}$ ratios.

Thus it seems that the BN crater works independently from the other craters. In contrast, the characteristics of the shallow degassing cells of the NE, V, and SE craters seem to be correlated, as shown by the similar variations of $\theta$ at the $V$ and $S E$ craters, when the NE crater became active. An injection of deep magma was detected at the $\mathrm{V}$ crater, at the time of the lava effusion observed at the NE crater, which could mean that the "magma chamber" is a common pool for both craters. In contrast, the SE crater appears to not be directly related to this magma source, since no 


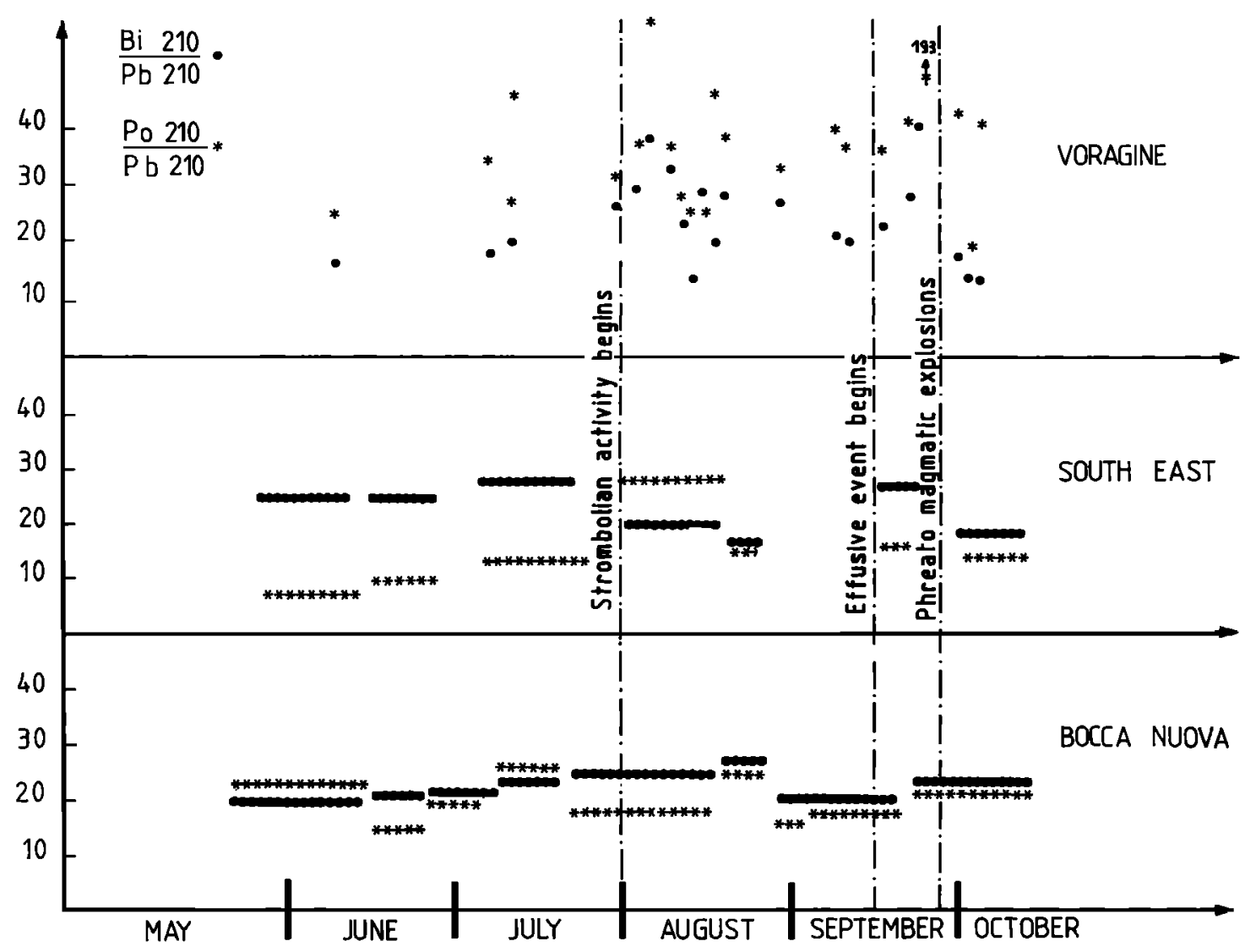

Fig. 2. Evolution of activity ratios at Mount Ema with time in 1986.

TABLE 2. Mean Values of Activity Ratios at the SE and BN Craters, and Dynamica1 Parameters Deduced

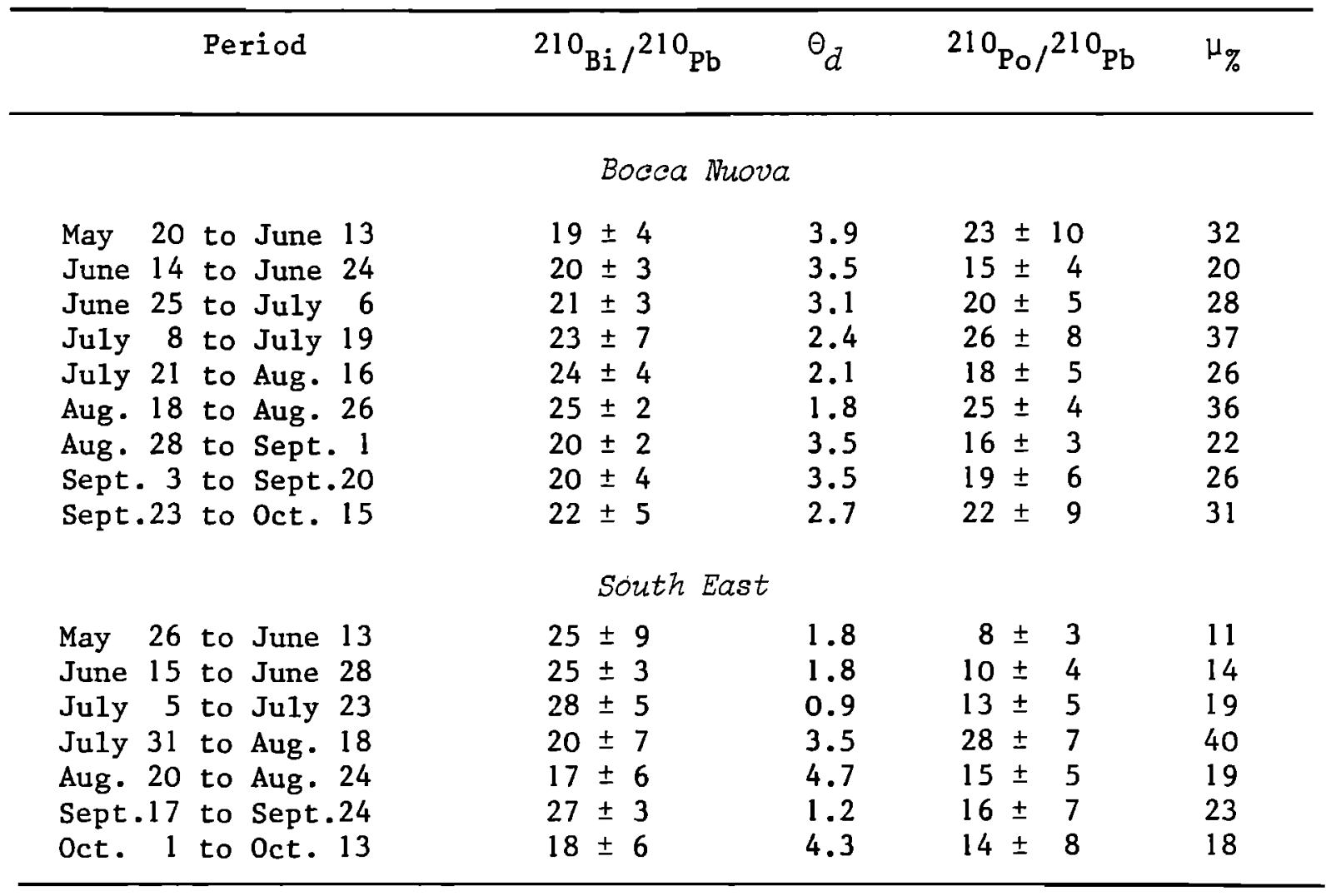


perturbation could be seen at the same time in the proporion of deep magma in the shallow cell; this is consistent with the low value of $\mu$ at this place.

However, it should be pointed out that seismic data seem to give different results [Cosentino et al., 1982] and we have no explanation for this discrepancy.

Acknowledgments. The authors are grateful to all the people who participated in this hard work: sampling on the rims of the craters. This work was supported by the "Programme Interdisciplinaire de Recherche pour la Prevision et la Surveillance des Eruptions Volcaniques" of the French CNRS. CFR contribution 896.

\section{REFERENCES}

Bennett, J. J., S. Krishnaswami, K. K. Turekian, M. G. Melson, and C. A. Hopson, The uranium and thorium decay series nuclides in Mount St. Helens effusives, Earth Planet. Sci. Let., $60,60-69,1982$.

Buat-Ménard, P., and M. Arnold, The heavy chemistry of atmospheric particulate matter emitted by Mount Etna volcano. Geophys. Res. Lett., S, 245-248, 1978.

Cadle, R. D. A. L. Lazrus, B. J. Huebert, L. E. Heidt, W. I. Rose Jr., D. C. Woods, R. L. Chuan, R. E. Stoiber, D. B. Smith, and R. A. Zielenski, Atmospheric implication studies of Central American volcanic eruption clouds, J.Geophys.Res., 84, 6961-6968, 1979.

Chester, D. K., A. M. Duncan, J. E. Guest, and C. R. J. Kilburn, Mount Etna: The anatomy of a Volcano, Stanford University Press, Stanford, (Calif.), 1985.

Cosentino, M., G. Lombardo, G. Patane, R. Schick, and A. D. L. Sharp, Seismological research on Mount Euna: State of the art and recent trends, Mem. Soc. Geol, 23, 159-202, 1982.
Gill, J., R. Williams, and K. Bruland, Eruption of basalt and andesite lava degasses ${ }^{222} \mathrm{Rn}$ and ${ }^{210} \mathrm{Po}$, Geophys. Res. Lett, 12, 17-20, 1985.

Kieffer, G., and J. C. Tanguy, L'activité de l'Etna en 1986, Bull. Soc. Geol. Fr., 3, 3-6, 1987.

Lambert, G., P. Bristeau, and G. Polian, Emission and enrichments of radon daughters from Etna volcano magma, Geophys. Res. Lett. , 3, 724-726, 1976.

Lambert, G. P. Bristeau, F. Le Guern, G. Polian, and J. C. Sabroux, Caractérisation des gaz magmatiques et fumerolliens par leurs aérosols radioactifs, C. R. Acad. Sci., Sér. D, 288 , 743- 746, 1979.

Lambert, G., M. F. Le Cloarec, B. Ardouin, and $J$. C. Le Roulley, Volcanic emission of radionuclides and magma dynamics, Earth Planet. Sci. Lett., 76, 185-192, 1985/86.

Le Cloarec, M. F., G. Lambert, J. C. Le Roulley, and $B$. Ardouin, Echanges de mattriaux volatils entre phases solide, liquide et gazeuse au cours de l'éruption de l'Euna de 1983, C.R. Acad. Sci., Sér. 2, 298, 805-808, 1984.

Le Guern, F., Les débits de $\mathrm{CO}_{2}$ et de $\mathrm{SO}_{2}$ volcaniques dans l'atmosphère, Bull. Volcanol., 45, 197-202, 1982.

Phelan, J. M., D. L. Finnegan, D. S. Ballantine, W. H. Zoller, M. A. Hart, and J. L. Moyers, Airbome aerosol measurements in the quiescent plume of Mount St. Helens: September 1980. Geophys. Res. Lett., 9, 1093-1096, 1982.

Polian, G., and G. Lambert, Radon daughters and sulfur output from Erebus volcano, Antarctica, J. Volcanol. Geotherm. Res.,6, 125-137, 1979.

B. Ardouin, G. Lamber, M. F. Le Cloarec, J. C. Le Roulley, and M. Pennisi, Centre des Faibles Radioactivites, Laboratoire Mixte CNRS/CEA. Avenue de ba Terrasse, 91198 Gif sur Yvette, France.

Received May 20, 1987;

revised October 1, 1987;

socepted November 5,1987.) 